\title{
Distribution of the highly toxic clinging jellyfish Gonionemus sp. around the island of Martha's Vineyard, Massachusetts, USA
}

\author{
Mary R. Carman ${ }^{1}$, David W. Grunden², Emily Reddington ${ }^{3}$ and Annette F. Govindarajan ${ }^{4 *}$
}

\begin{abstract}
In recent years, the cryptogenic and often highly toxic hydrozoan Gonionemus sp. has appeared in new locations around the globe and has become increasingly abundant in the Northwest Atlantic where it is now associated with severe stings. Several such stings have been documented from the island of Martha's Vineyard, located approximately $8 \mathrm{~km}$ south of the Cape Cod, Massachusetts coast. It appears that Gonionemus sp. may be expanding its range in this region. Here we surveyed for medusae in the major coastal ponds along the perimeter of Martha's Vineyard, refined our knowledge of Gonionemus sp. habitat by recording salinity, water depth, and bottom type from surveyed areas, and obtained a basic population life history assessment by measuring the sizes and sex ratios of medusae collected in the surveys. We found Gonionemus sp. present in five ponds: Farm Pond, Sengekontacket Pond, Lake Tashmoo, Stonewall Pond, and Edgartown Great Pond. Medusae were associated with eelgrass meadows in all cases. Salinities for medusa populations ranged from $18 \mathrm{ppt} \mathrm{in} \mathrm{Edgartown} \mathrm{Great} \mathrm{Pond} \mathrm{to} 29 \mathrm{ppt}$ in the other ponds. The Farm Pond and Stonewall Pond medusae were significantly smaller than those from other ponds and were comprised of primarily immature individuals despite sampling relatively later in the season, suggesting factors other than temperature may be affecting medusa growth. For mature medusae, sex ratios were highly biased, suggesting a strong clonal component to population growth. Edgartown Great Pond contained only males and thus may represent an entirely clonal population. These medusae are the first record of Gonionemus sp. in Edgartown Great Pond, despite a long history of study. Medusae were most abundant in the portion of the pond near the town landing, which suggests that the medusae could have originated by clonal polyps, frustules, or cysts associated with a boat hull. Given the presence of male and female medusae in other parts of Martha's Vineyard, it seems likely that additional genetic individuals will arrive in the near future, potentially establishing a sexually reproductive population.
\end{abstract}

Keywords: Gonionemus, Hydrozoa, Martha's Vineyard, Polyp, Cyst, Asexual reproduction, Clones, Cryptogenic, Eelgrass

\section{Background}

The hydrozoan jellyfish Gonionemus sp. (Fig. 1) is an often highly toxic, cryptogenic species that has become increasingly abundant in the Cape Cod region of Massachusetts, USA in recent years. Gonionemus was originally known from this region in the 1890s and early 1900s (referred to as Gonionemus murbachii), but nearly died out when its eelgrass habitat succumbed to a wasting disease in the 1930s (Govindarajan and Carman 2016). At least one small population on the island of Martha's Vineyard was

\footnotetext{
* Correspondence: afrese@whoi.edu

${ }^{4}$ Biology Department, MS\#33, Woods Hole Oceanographic Institution, Woods Hole, MA 02543, USA

Full list of author information is available at the end of the article
}

able to persist through the twentieth century. However, the jellyfish began a regional resurgence around 1990 and became associated, for the first time, with severe stings similar to those described from Northwest Pacific and Sea of Japan populations, including severe joint and muscle pain, respiratory difficulties, and neurological symptoms (Pigulevsky and Michaleff 1969; Yakovlev and Vaskovsky 1993). These observations suggested a cryptic invasion of a new, more toxic lineage (Govindarajan and Carman 2016). Similar recent sightings that possibly indicate new invasions have occurred elsewhere around the world, including in Argentina (Rodriguez et al. 2014), the US mid-Atlantic region (Gaynor et al. 2016), the French

(c) The Author(s). 2019 Open Access This article is distributed under the terms of the Creative Commons Attribution 4.0 International License (http://creativecommons.org/licenses/by/4.0/), which permits unrestricted use, distribution, and reproduction in any medium, provided you give appropriate credit to the original author(s) and the source, provide a link to the Creative Commons license, and indicate if changes were made. The Creative Commons Public Domain Dedication waiver (http://creativecommons.org/publicdomain/zero/1.0/) applies to the data made available in this article, unless otherwise stated. 


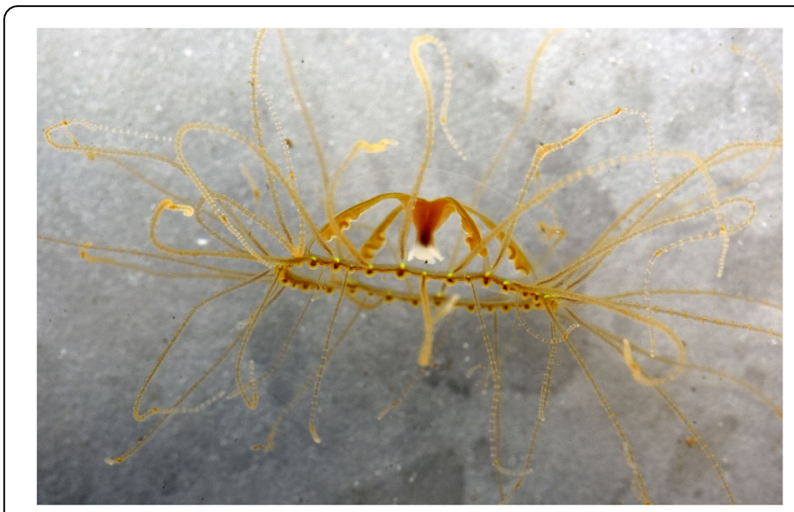

Fig. 1 Side view of Gonionemus sp., Farm Pond, July 9, 2018. Photo credit: Dann Blackwood, US Geological Survey Woods Hole

Mediterranean coast (Marchessaux et al. 2017), and the Swedish west coast (Govindarajan et al. 2019).

Gonionemus sp. has a complex life cycle that includes an adult medusa stage, a planula larval stage, and a benthic polyp stage, that allows for numerous dispersal mechanisms (Perkins 1903, Joseph 1925, Mikulich 1970, Kakinuma 1971). The adult medusae can reach up to $3 \mathrm{~cm}$ in diameter (Govindarajan et al. 2017) and have adhesive structures located towards the distal ends of their tentacles which they use to cling to eelgrass (Kramp 1961; Bakker 1980). Fertile adults release gametes which fertilize and form planula larvae, which settle and develop into polyps. The polyps reach up to $2 \mathrm{~mm}$ in size and are nearly impossible to find in nature (Perkins 1903). Gonionemus sp. can also form asexual frustules and cysts, which can develop into polyps and medusae (Kakinuma 1971; Uchida 1976). Thus, this species can disperse via medusae, through independent drifting or rafting on eelgrass; via drifting of the planula larvae; and rafting of polyps, frustules, and medusae on eelgrass or algal substrates. All of these stages could potentially be dispersed anthropogenically through a variety of mechanisms, including incidental transport on boat hulls, shellfish, and seaweeds (e.g., Tambs-Lyche 1964; Edwards 1976).

The distribution of Gonionemus sp. on Martha's Vineyard, known for decades from one pond (Sengekontacket Pond) appears to have expanded significantly throughout the island over the past several years (Govindarajan and Carman 2016). Martha's Vineyard is a popular tourist destination and the occurrence of severe stings is of great concern from both human health and economic perspectives. Additionally, high densities of Gonionemus sp. may have a negative effect on the inhabitants of Martha's Vineyard eelgrass ecosystems as it is potentially lethal to predators (Carman et al. 2017). Thus, it is important to understand its regional distribution, habitat constraints, and spread in this area. The goals of this study were to document Gonionemus sp. from coastal ponds along the perimeter of the island, refine our knowledge of the species habitat by recording salinity, water depth, and bottom type from surveyed areas, and obtain a basic population life history assessment by measuring the sizes and sex ratios of medusae collected in the surveys.

\section{Methods}

\section{Study areas}

Martha's Vineyard is an approximately $260 \mathrm{~km}^{2}$ roughly triangular-shaped island located $8 \mathrm{~km}$ south of Cape Cod in the state of Massachusetts, USA (Fig. 2). Its coastline consists of several inlets and coastal ponds that vary in salinity, eelgrass cover, and connectivity to the ocean (Oldale 2001). All major coastal ponds around the perimeter of the island were surveyed (Table 1; Fig. 2). For Farm and Sengekontacket Ponds, two sites within each that had different bottom types were surveyed. For Edgartown Great Pond, 12 stations were surveyed over multiple days as part of a larger monitoring effort for pond health (Fig. 3).

\section{Survey methods}

Surveys for Gonionemus sp. were conducted between June 26 and September 4, 2018.

Sites were accessed with small boats and medusae were searched for by snorkeling and wading. Medusae were collected using hand-held nets with $3 \mathrm{~mm}$ mesh, counted, and secured in coolers. Latitude and longitude (using a Garmin Etrex Vista HC GPS unit), surface salinity (using ATC hand held refractometer or a YSI ProDSS water quality meter), and vegetation type were recorded. The coolers of medusae were carried to the Wood Hole Oceanographic Institution for laboratory analysis.

\section{Laboratory measurements and observations}

Each medusa specimen was examined alive under a dissecting microscope and the sex, size (umbrella diameter), and unusual morphological variations were recorded. Males and females were distinguished through examination of their gonads (Costello et al. 1957). Often females were observed releasing their eggs, which are $80-90 \mu \mathrm{m}$ in diameter (Perkins 1903), likely in response to the microscope light source (e.g., Rugh 1929). Occasionally, males were observed shedding sperm. Medusae were then preserved in $100 \%$ ethanol for future genetic analyses. Size data were analyzed with Matlab r2015b. As assessed by the ShapiroWilk test and Levene's test, analysis of variance (ANOVA) assumptions of normality and homogeneity of variances were not met. Therefore, a Kruskal-Wallis test followed by Dunn's multiple comparisons test was used to compare medusa sizes from different locations. A regression analysis was used to assess the relationship between size and sampling date. 


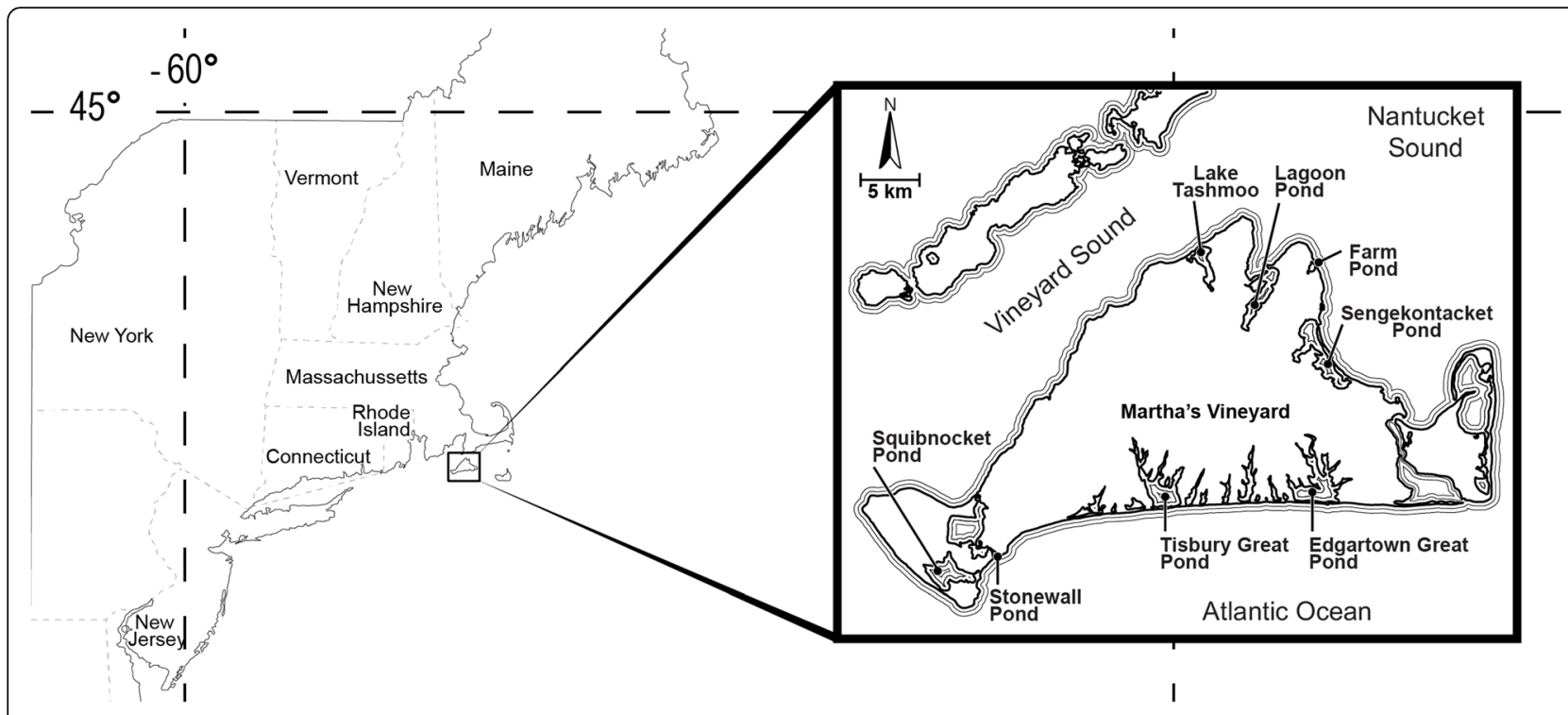

Fig. 2 Survey sites on Martha's Vineyard

\section{Results}

\section{Survey findings}

A total of 28 surveys were conducted in eight coastal ponds, some with multiple survey sites (Table 1; Table 2). Five of these ponds, spanning all sides of the island, contained Gonionemus sp. Specifically, Gonionemus sp. was present at Farm Pond (southern section), Sengekontacket Pond (Major's Cove section), Edgartown Great Pond (7 out of 12 sampling sites), Stonewall Pond, and Lake Tashmoo. Surveying was conducted four times in Farm Pond in order to attempt to obtain sexually mature specimens. Medusae collected from the first three Farm Pond surveys were not measured and were discarded after initial inspection (Table 2).

Gonionemus sp. were more abundant in Farm Pond and Stonewall Pond than in Sengekontacket Pond, Lake Tashmoo, and Edgartown Great Pond (Table 2). Edgartown Great Pond surveys were conducted independently and therefore abundances were not directly comparable to the other ponds. Like in Farm Pond, the medusae in Stonewall
Pond were primarily immature (Table 2). In all ponds, Gonionemus was only found in survey areas with eelgrass. They were not found in areas with non-eelgrass vegetation, even if those areas were within the same pond, as in Farm Pond and Sengekontacket Pond. Medusae were found within a relatively broad range of salinities, ranging from 18 ppt in Edgartown Great Pond to 29 ppt in Farm Pond, Sengekontacket Pond, Stonewall Pond, and Lake Tashmoo.

\section{Size and sex ratios}

Overall, size of medusae varied considerably, ranging from $1.28 \mathrm{~cm} \pm 0.10$ at Farm Pond on August 3rd to $2.37 \mathrm{~cm} \pm 0.31$ from Lake Tashmoo on July 27th (Table 2; Fig. 4). There was no significant relationship with date $\left(\mathrm{R}^{2}=0.0184, p=0.065\right.$; Fig. 4). Medusa varied significantly in size between populations (Kruskal-Wallis test followed by Dunn's multiple comparison test; $P<0.05$; with medusae from Farm Pond and Stonewall Pond significantly smaller than those from Sengekontacket Pond,

Table 1 Survey site characteristics

\begin{tabular}{lllll}
\hline Pond & Region & Max depth $(\mathrm{m})$ & Access to the sea & Eelgrass \\
\hline Lake Tashmoo & north & 3 & Narrow channel to Vineyard Sound & Patchy throughout \\
Lagoon Pond & north & 8 & Narrow channel to Nantucket Sound & none \\
Farm Pond & northeast & 1.5 & Culvert to Nantucket Sound & Southern part of pond \\
Sengekontacket Pond & east & 3 & 2 inlets to Nantucket Sound & Back portion and Major's Cove \\
Edgartown Great Pond & south & 3 & Barrier breaches to Atlantic Ocean & Most portions \\
Tisbury Great Pond & south & 3 & Barrier breaches to Atlantic Ocean & none \\
Stonewall Pond & southwest & 3 & Exposed to Vineyard Sound & Patchy throughout \\
Squibnocket Pond & southwest & 1.5 & Barrier breaches and through Menemsha Pond & none \\
\hline
\end{tabular}




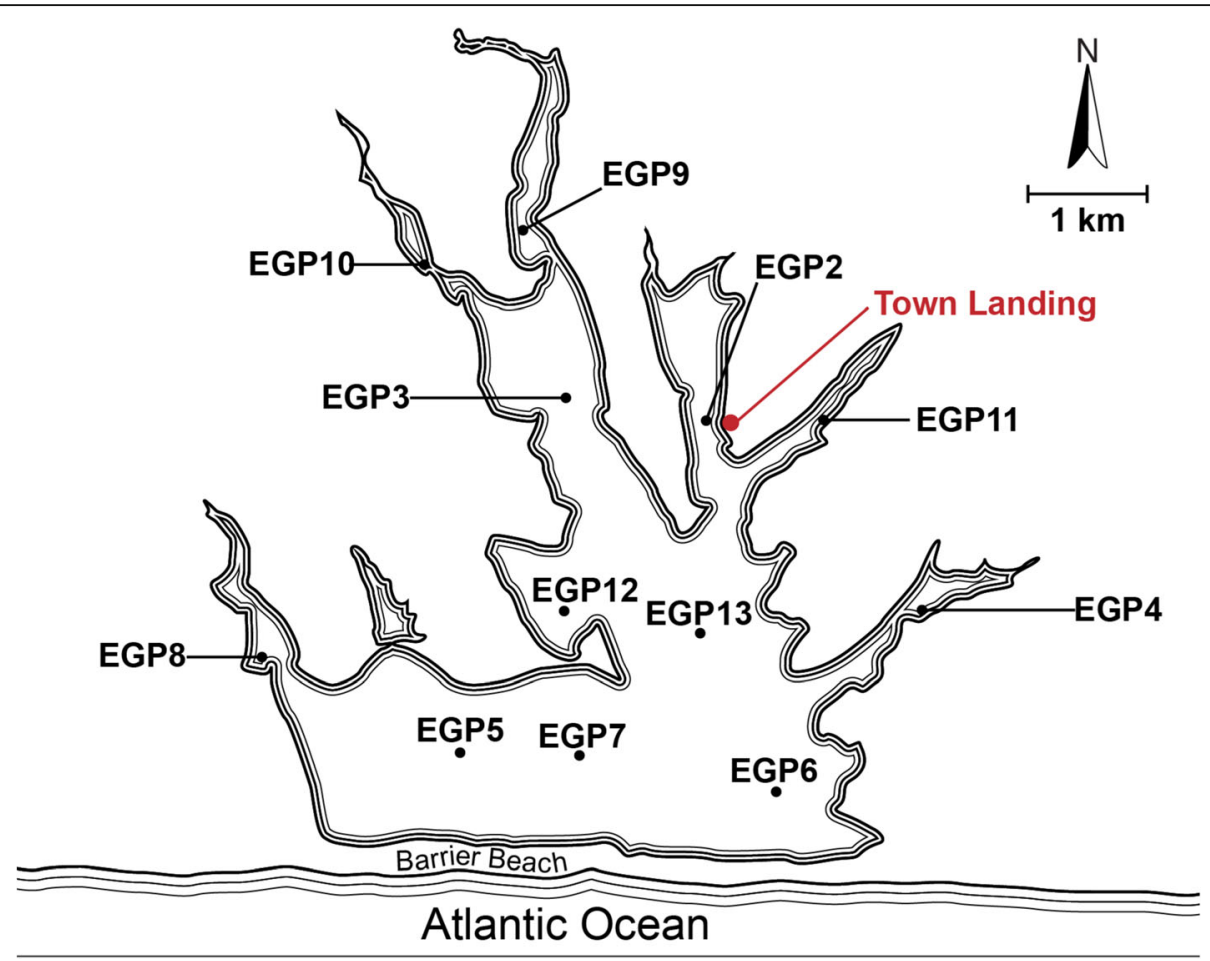

Fig. 3 Sampling stations in Edgartown Great Pond

Edgartown Great Pond (EGP, Lake Tashmoo). The populations with larger medusae had a greater percentage of sexually mature medusae. Between 94 and $100 \%$ of medusae collected from Sengekontacket Pond, Edgartown Great Pond, and Lake Tashmoo were sexually mature, but only approximately one third of medusae from Farm Pond and Stonewall Pond were mature (Table 3). The sex ratio of mature medusae did not approximate 1:1 at any site and varied between sites (Table 2). There were $0.50-0.60$ females per male in Farm Pond, Sengekontacket Pond, and Stonewall Pond and 1.4 females per male in Lake Tashmoo. All 34 medusae examined from the Edgartown Great Pond sites were male.

\section{Symmetry deviations and additional observations}

Only 4 out of the 188 medusae (2.1\% percent) examined exhibited symmetry deviations, all of which were males. One individual from Sengekontacket Pond (Majors Cove) possessed 5 radial canals, and one individual from Farm Pond (south) possessed 5 radial canals and another possessed 3 radial canals. A fourth individual from Farm Pond (south) had 4 radial canals, one of which had an abnormal outgrowth that resembled a manubrium.

Often, medusae appeared to feed on plankton stirred up by the collection process. In two observations (from Farm Pond and Lake Tashmoo), the engulfed prey produced noticeably enlarged stomachs. In the Lake Tashmoo medusa, the prey item was able to be identified as a three-spined stickleback fish (Gasterosteus aculeatus).

\section{Discussion}

Gonionemus sp. medusae were found in five coastal ponds distributed around the island. Medusae had been previously reported from four of these (Farm Pond, Sengekontacket Pond, Stonewall Pond, and Lake Tashmoo; Govindarajan and Carman 2016). This is the first record of Gonionemus sp. medusae in Edgartown Great Pond. It is likely that this represents a recent range expansion, as the Great Pond Foundation and Edgartown Shellfish Department have monitored the pond for decades (Reddington 2018; Howes et al. 2008) and would almost certainly have been observed it if it were present.

Medusae were not found in Squibnocket Pond, although they had been reported there previously (Govindarajan and Carman 2016). Squibnocket Pond ranges in salinity from fresh to brackish depending on the location within the pond and the presence of salt water over-wash (Howes et al. 2017). However, Gonionemus sp. medusae are not found in freshwater (although note Todd, 1966 refers medusae found in British Columbian waters with zero salinity, but this may apply to Gonionemus vertens), so it is unlikely that medusae can exist in Squibnocket Pond over a long period of time. We found several medusae in Edgartown Great Pond where the salinity reached as low as $18 \mathrm{ppt}$ 
Table 2 Survey summaries. All medusae found were saved for size and sexual development measurements unless otherwise stated

\begin{tabular}{|c|c|c|c|c|c|c|}
\hline Site & Coordinates & Plant/algal substrate & Date & Salinity & \# found & Notes \\
\hline Farm Pond - north & $\begin{array}{l}41.4484 \\
-70.5548\end{array}$ & Sargassum & July 23 & 29 & 0 & \\
\hline \multirow[t]{4}{*}{ Farm Pond - south } & \multirow{4}{*}{$\begin{array}{l}41.4463 \\
-70.5567\end{array}$} & \multirow[t]{4}{*}{ Zostera } & July 9 & & $35^{*}$ & *not saved \\
\hline & & & July 23 & \multirow[t]{3}{*}{29} & $35^{*}$ & ${ }^{*}$ not saved \\
\hline & & & July 30 & & $65^{*}$ & ${ }^{*}$ not saved \\
\hline & & & Aug 3 & & 44 & \\
\hline Sengekontacket Pond - Majors Cove & $\begin{array}{l}41.4164 \\
-70.5690\end{array}$ & Zostera & July 16 & 29 & 34 & \\
\hline Sengekontacket Pond - Trapps Pond & $\begin{array}{l}41.4014 \\
-70.5278\end{array}$ & Gracilaria & Sept 8 & 28 & 0 & \\
\hline Edgartown Great Pond - EGP2 & $\begin{array}{l}41.3669 \\
-70.5515\end{array}$ & Zostera & Aug 5 & 19 & 1 & \\
\hline Edgartown Great Pond - EGP3 & $\begin{array}{l}41.3677 \\
-70.5586\end{array}$ & Zostera & July 3 & 18 & 3 & \\
\hline \multirow[t]{3}{*}{ Edgartown Great Pond - EGP4 } & \multirow{3}{*}{$\begin{array}{l}41.3596 \\
-70.5410\end{array}$} & \multirow[t]{3}{*}{ Zostera } & July 12 & 21 & $11^{*}$ & *9 saved \\
\hline & & & July 19 & 19 & 1 & \multirow[t]{2}{*}{${ }^{*}$ not saved } \\
\hline & & & Aug 5 & 19 & 20 & \\
\hline Edgartown Great Pond - EGP5 & $\begin{array}{l}41.3544 \\
-70.5638\end{array}$ & Zostera & Aug 14 & 19 & 1 & \\
\hline Edgartown Great Pond - EGP6 & $\begin{array}{l}41.3530 \\
-70.5482\end{array}$ & Zostera & July 19 & 20 & 0 & \\
\hline Edgartown Great Pond - EGP7 & $\begin{array}{l}41.3543 \\
-70.5579\end{array}$ & Zostera & July 8 & 20 & $2^{*}$ & *not saved \\
\hline Edgartown Great Pond - EGP8 & $\begin{array}{l}41.3577 \\
-70.5736\end{array}$ & Zostera & July 19 & 20 & 0 & \\
\hline Edgartown Great Pond - EGP9 & $\begin{array}{l}41.3741 \\
-70.5609\end{array}$ & sediment & July 19 & 16 & 0 & \\
\hline Edgartown Great Pond - EGP10 & $\begin{array}{l}41.3728 \\
-70.5658\end{array}$ & sediment & July 19 & 17 & 0 & \\
\hline Edgartown Great Pond - EGP11 & $\begin{array}{l}41.3667 \\
-70.5456\end{array}$ & Zostera & July 12 & 19 & $2^{*}$ & ${ }^{*}$ not saved \\
\hline \multirow[t]{3}{*}{ Edgartown Great Pond - EGP12 } & \multirow{3}{*}{$\begin{array}{l}41.3602 \\
-70.5586\end{array}$} & \multirow[t]{3}{*}{ Zostera } & July 12 & 19 & $1^{*}$ & *not saved \\
\hline & & & July 24 & 20 & $1^{*}$ & ${ }^{*}$ not saved \\
\hline & & & Aug 14 & 18 & $1^{*}$ & *not saved \\
\hline Edgartown Great Pond - EGP13 & $\begin{array}{l}41.3593 \\
-70.5521\end{array}$ & sediment & July 19 & 19 & 0 & \\
\hline Tisbury Great Pond & $\begin{array}{l}41.3542 \\
-70.6460\end{array}$ & sediment & July 31 & 13 & 0 & \\
\hline Stonewall Pond & $\begin{array}{l}41.3252 \\
-70.7575\end{array}$ & Zostera & July 24 & 29 & 64 & \\
\hline Squibnocket Pond & $\begin{array}{l}41.3157 \\
-70.7833\end{array}$ & Ruppia & July 31 & 0 & 0 & \\
\hline Lake Tashmoo & $\begin{array}{l}41.4546 \\
-70.6251\end{array}$ & Zostera & July 27 & 28 & 12 & \\
\hline Lagoon Pond & $\begin{array}{l}41.4315 \\
-70.6018\end{array}$ & sediment & Aug 3 & 27 & 0 & \\
\hline
\end{tabular}

(Table 2). In general, salinity in coastal ponds such as the ones we surveyed here is highly variable and so future laboratory studies that assess salinity tolerances of Gonionemus sp. life stages will be extremely valuable for understanding its range expansion and persistence in new locations.

Gonionemus sp. medusae were only found at sites with eelgrass. Both Farm Pond and Sengekontacket Pond 


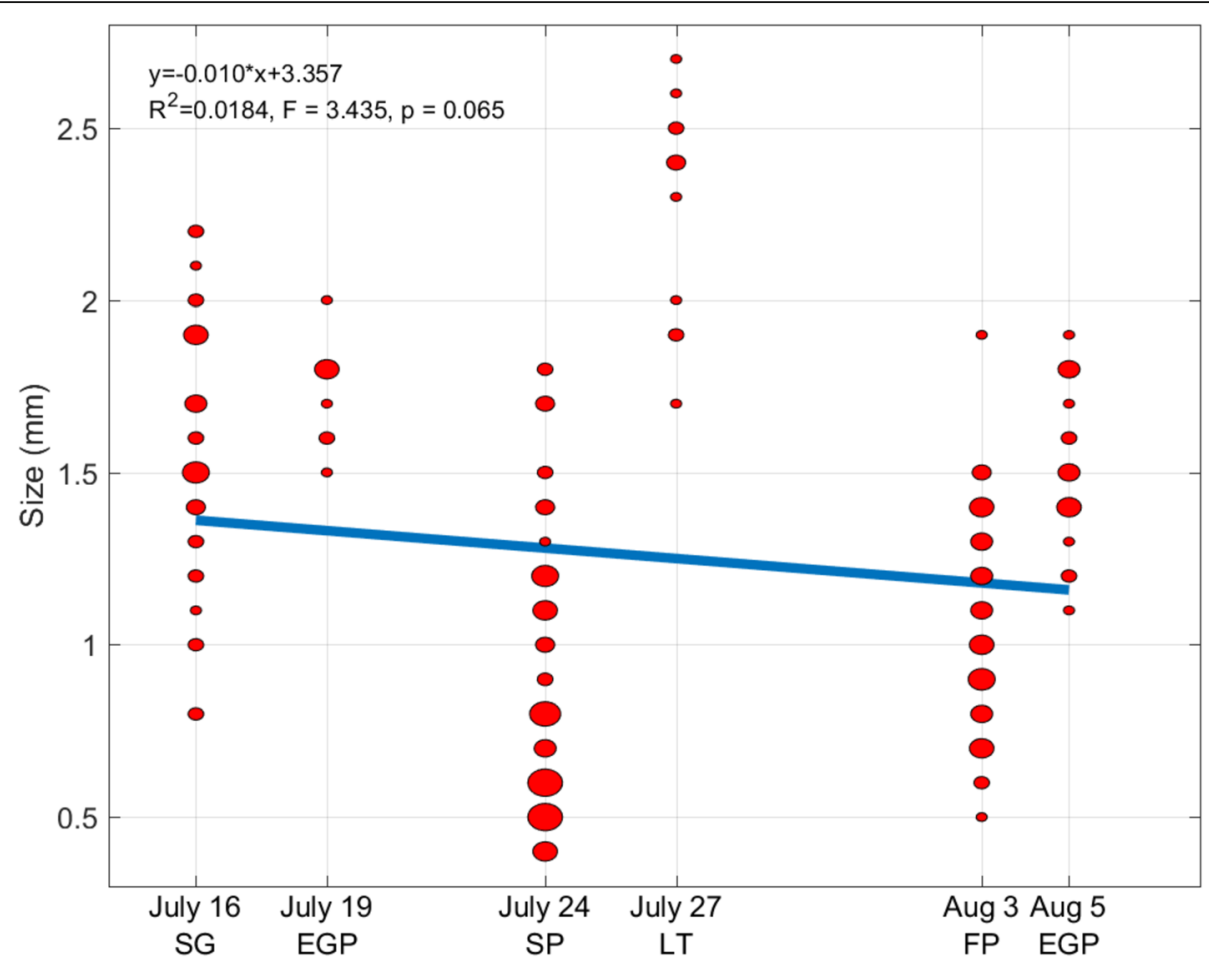

Fig. 4 Size (umbrella diameter) distributions as a function of survey date. Oval size is proportional to the number of medusae possessing that particular umbrella diameter

contain areas with eelgrass and areas dominated by macroalgae (Sargassum or Gracilaria), but medusae were only found in the eelgrass regions. This species has been found with eelgrass and other seagrasses or macroalgae in other locations (Bakker 1980) suggesting that it is not an obligate eelgrass associate. Thus, it is possible that other environmental factors associated with the eelgrass meadows are restricting the distribution of Gonionemus sp. medusae in Farm Pond and Sengekontacket Pond, rather than the eelgrass directly.

Surveyed populations spanned a range of size distributions that, interestingly, did not correlate with sampling date. Farm Pond and Stonewall Pond had significantly smaller medusae than other ponds. Both differences in prey density and temperature can contribute to differential medusa growth rates in Gonionemus (Kakinuma 1971) and other hydromedusan species (Arai 1992; Matsakis
1993). Although we do not have temperature records for our sites, the fact that the Stonewall and Farm Pond collections were made middle to late in the season suggests that factors other than temperature could be influencing population growth rates.

The presence of an all-male population in Edgartown Great Pond (EGP) is consistent with a recent invasion of the pond through clonally-derived asexual propagules. This mechanism may be a common feature for many hydrozoan invasive species. In the closely-related globally invasive freshwater hydromedusa Craspedacusta sowerbyi, unisexual clonal populations are the norm (Acker and Muscat 1976) and colonization likely occurs through polyps or cysts, potentially via aerial dispersal by birds ("ornithochory"; Dumont 1994). Another globally invasive hydrozoan, Cordylophora caspia, is also capable of asexual reproduction and cyst formation (Folino-Rorem et al. 2009).

Table 3 Size and sex ratio data for the sites where Gonionemus sp. was found

\begin{tabular}{|c|c|c|c|c|c|c|c|}
\hline \multirow[t]{2}{*}{ Site } & \multicolumn{2}{|c|}{ Females } & \multicolumn{2}{|c|}{ Males } & \multicolumn{2}{|c|}{ Immature } & \multirow{2}{*}{$\begin{array}{l}\text { Sex ratio (\# } \\
\text { females per male }\end{array}$} \\
\hline & \# & Diameter (mm \pm s.d.) & $\#$ & Diameter $(m m \pm$ s.d. $)$ & $\#$ & Diameter $(m m \pm$ s.d.) & \\
\hline Farm Pond - south & 6 & $1.28 \pm 0.10$ & 12 & $1.35 \pm 0.23$ & 26 & $0.87 \pm 0.22$ & 0.50 \\
\hline Sengekontacket Pond - Majors Cove & 12 & $1.47 \pm 0.26$ & 20 & $1.69 \pm 0.35$ & 2 & $0.80 \pm 0$ & 0.60 \\
\hline Edgartown Great Pond (EGP-3 and EGP-4 pooled) & 0 & $\mathrm{n} / \mathrm{a}$ & 34 & $1.63 \pm 0.26$ & 0 & $\mathrm{n} / \mathrm{a}$ & 0 \\
\hline Stonewall Pond & 8 & $1.36 \pm 0.27$ & 14 & $1.36 \pm 0.24$ & 42 & & 0.57 \\
\hline Lake Tashmoo & 7 & $2.37 \pm 0.31$ & 5 & $2.14 \pm 0.3$ & 0 & $\mathrm{n} / \mathrm{a}$ & 1.40 \\
\hline
\end{tabular}


However, despite its high potential for clonal dispersal, a genetic analysis indicated that this species may spread primarily through sexually-derived propagules (Darling and Folino-Rorem 2009). Similarly, Meek et al. (2013) found high levels of genetic diversity in the invasive hydrozoans Maeotias marginata and Moerisia sp. suggesting that colonization could be the product of sexual reproduction, multiple introductions and/or a large number of founding individuals, although there was evidence for asexual reproduction that could facilitate propagation. The presence of fertile males and females in all of our other Martha's Vineyard sites, and the inconsistently skewed sex ratios, suggest that both asexual and sexual reproduction are important. It also seems possible that Edgartown Great Pond is currently colonized by a single male clone, but, given the close proximity of Edgartown Great Pond to other Gonionemus sp. sites, it is very likely that additional colonizers will arrive and ultimately enable a sexually reproducing population. Future genetic studies will help elucidate the roles of sexual and asexual reproduction in Gonionemus sp. spread (e.g., Reitzel et al. 2013).

In Edgartown Great Pond, there is a single town landing for public boat access located in the mid-area of Meshacket Cove, near station EGP-2 (Fig. 3). The greater abundance of Gonionemus sp. at this station and surrounding stations EGP-3, 4, 11 (Table 2) and the fact that individuals were first observed adjacent to the town landing, suggest that the introduction could have occurred here, perhaps by polyps, frustules, or cysts attached to a boat hull, even if the boat had been trailered to the landing from elsewhere. In other hydrozoans, cysts can sometimes survive desiccation and cleaning procedures (Purcell et al. 1999), and it is likely that Gonionemus sp. can as well, based on its sporadic presence in some aquaria (e.g., reviewed in Edwards 1976; Bakker 1980).

Given the growing distribution of Gonionemus sp. on Martha's Vineyard and elsewhere and the high potential for its continued dispersal, it is important to obtain a greater understanding of its biology and ecological roles. In many Gonionemus sp. populations, a greater or lesser number of radial canals (e.g., Hargitt 1901; Perkins 1903; Rugh 1930; Marchessaux et al. 2017) as well as variations in manubrium development (Rugh 1930) is sometimes observed. Overall, we saw radial canal abnormalities in $2 \%$ of the specimens we observed, compared to $~ 5 \%$ in the former Woods Hole, MA population (Hargitt 1901) and $\sim 10 \%$ in a coastal Mediterranean population (Marchessaux et al. 2017). The significance of this abnormality is unclear. Similar variations have been observed in some scyphozoans (Gershwin 1999). In Gonionemus sp., radial canal variations may be a result of developmental process (Perkins 1903), but they are also speculated to be associated with pollution (Marchessaux et al. 2017).
More information is needed about the ecology and trophic roles of Gonionemus sp. This species feeds on small zooplankton such as copepods, amphipods, and isopods (Bakker 1980; Yakovlev and Vaskovsky 1993). Here we observed that Gonionemus sp. medusae are capable of consuming fishes that approach their own size. While our observation was likely the product of the medusa and fish brought to close proximity during the collecting process, it raises the issue of the impact of Gonionemus sp. medusae on Martha's Vineyard fish populations. Eelgrass meadows are known to be nursery habitat for many fish species, and high densities of medusae could result in significant juvenile fish mortality. Gonionemus sp. medusae could also potentially impact organisms larger than themselves that they do not consume. For example, Carman et al. (2017) observed that consumption of multiple medusae by crabs could result in crab deaths.

Over the past three decades at Martha's Vineyard, Gonionemus sp. has shifted from having a highly restricted distribution in Sengekontacket Pond, known only to a handful of individuals, to a relatively high profile threat to public health around the island (Govindarajan and Carman 2016). Here we show that Gonionemus sp. hotspots are located in most major coastal ponds around the island. We also suggest that clonal reproduction may be an important component of Gonionemus sp. population growth and may contribute to its expansion into new areas. Gonionemus sp. medusae appear sensitive to environmental conditions, and continued monitoring and surveys of other areas at risk for invasion are warranted, as well as studies on its ecological interactions with other species.

\section{Acknowledgements}

We thank Jason Mallory and Gedeon Pil, Oak Bluffs Shellfish Department; Danielle Ewart, Tisbury Shellfish Department; Isaiah Scheffer and William Reich, Chilmark Shellfish Department; Sam Hartman and Spencer Goldsmith, Great Pond Foundation; Marley Kaplan and Amanda Josephson, Friends of Sengekontacket; Warren Gaines, Edgartown Shellfish Department; Hannah Gonzales, Lagoon Pond Association; and Dann Blackwood, US Geological Survey, Woods Hole, for field assistance. We thank Dana Yoerger, Woods Hole Oceanographic Institution, for assistance with Matlab.

\section{Funding}

Funding was provided by the Oak Bluffs Community Preservation Committee, the Oak Bluffs Shellfish Department, Great Pond Foundation, the Edey Foundation, and the USGS-WHOI Cooperative Program.

\section{Availability of data and materials}

The dataset supporting the conclusions of this article is included within the article.

\section{Authors' contributions}

$M C, D G$, and ER obtained funding for the study and conducted the surveys. AG conducted the laboratory measurements and analyses. AG and MC drafted the manuscript and DG and ER provided edits. All authors read and approved the final manuscript.

Ethics approval and consent to participate Not applicable. 


\section{Consent for publication}

All authors consent for publication

\section{Competing interests}

The authors declare that they have no competing interests.

\section{Publisher's Note}

Springer Nature remains neutral with regard to jurisdictional claims in published maps and institutional affiliations.

\section{Author details}

'Biology Department, MS\#8, Woods Hole Oceanographic Institution, Woods Hole, MA 02543, USA. ${ }^{2}$ Oak Bluffs Shellfish Department, Oak Bluffs, MA 02557, USA. ${ }^{3}$ Great Pond Foundation, Edgartown, MA 02539, USA. ${ }^{4}$ Biology Department, MS\#33, Woods Hole Oceanographic Institution, Woods Hole, MA 02543, USA.

Received: 24 December 2018 Accepted: 4 April 2019

Published online: 02 May 2019

\section{References}

Acker TS, Muscat AM. The ecology of Craspedacusta sowerbii Lankester, a freshwater hydrozoan. Am Midl Nat. 1976;1:323-36.

Arai MN. Active and passive factors affecting aggregations of hydromedusae: a review. Sci Mar. 1992;56(2):99-108.

Bakker C. On the distribution of 'Gonionemus vertens' a. Agassiz (Hydrozoa, Limnomedusae), a new species in the eelgrass beds of Lake Grevelingen (SW Netherlands). Hydrobiol Bull. 1980;14(3):186-95.

Carman MR, Grunden DW, Govindarajan AF. Species-specific crab predation on the hydrozoan clinging jellyfish Gonionemus sp. (Cnidaria, Hydrozoa), subsequent crab mortality, and possible ecological consequences. PeerJ. 2017;5:e3966.

Costello DP, Davidson ME, Eggers A, Fox MH, Henley C. Methods for obtaining and handling marine eggs and embryos. Woods Hole: Marine Biological Laboratory; 1957.

Darling JA, Folino-Rorem NC. Genetic analysis across different spatial scales reveals multiple dispersal mechanisms for the invasive hydrozoan Cordylophora in the Great Lakes. Mol Ecol. 2009;18(23):4827-40

Dumont $\mathrm{HJ}$. The distribution and ecology of the fresh-and brackish-water medusae of the world. In: Studies on the ecology of tropical zooplankton. Dordrecht: Springer; 1994. p. 1-12.

Edwards C. A study in erratic distribution: the occurrence of the medusa Gonionemus in relation to the distribution of oysters. Adv Mar Biol 1976;14: 251-84.

Folino-Rorem NC, Darling JA, D'Ausilio CA. Genetic analysis reveals multiple cryptic invasive species of the hydrozoan genus Cordylophora. Biol Invasions. 2009;11(8):1869-82.

Gaynor JJ, Bologna PA, Restaino D, Barry CL. First occurrence of the invasive hydrozoan Gonionemus vertens a. Agassiz, 1862 (Cnidaria: Hydrozoa) in New Jersey, USA. Bioinvasion Rec. 2016;5(4):233-7.

Gershwin L. Clonal and population variation in jellyfish symmetry. J Mar Biol Assoc U K. 1999;79:993-1000.

Govindarajan AF, Carman MR. Possible cryptic invasion of the western Pacific toxic population of the jellyfish Gonionemus vertens (Cnidaria: Hydrozoa) in the northwestern Atlantic Ocean. Biol Invasions. 2016;18(2):463-9.

Govindarajan AF, Carman MR, Khaidarov MR, Semenchenko A, Wares JP. Mitochondrial diversity in Gonionemus (Trachylina:Hydrozoa) and its implications for understanding the origins of clinging jellyfish in the Northwest Atlantic Ocean. PeerJ. 2017:5:e3205.

Govindarajan AF, Kälström, B, Selander E, Östman C, Dahlgren TG. In Press. The highly toxic and cryptogenic clinging jellyfish Gonionemus sp. (Hydrozoa, Limnomedusae) on the Swedish west coast. PeerJ. https://doi.org/10.7717/ peer.6883.

Hargitt CW. Variation among hydromedusae, vol. 2. Woods Hole: Biological Bulletin Marine Biological Laboratory; 1901. p. 221-51.

Howes BL, Eichner EM, Samimy Rl, Ruthven HE, Schlezinger DR, Ramsey JS. Linked watershed-embayment model to determine the critical nitrogen loading threshold for the Menemsha-Squibnocket pond embayment system, Chilmark/Aquinnah, Massachusetts. Boston: SMAST/DEP Massachusetts estuaries project, Massachusetts Department of Environmental Protection; 2017.
Howes BL, Samimy RI, Schlezinger DR, Ramsey JS, Eichner EM. Linked watershedembayment model to determine critical nitrogen loading threshold for the Edgartown great pond system, Edgartown, MA. Final report. Boston: SMAST/ DEP Massachusetts estuaries project, Massachusetts Department of Environmental Protection; 2008.

Joseph H. Zur Morphologie und Entwicklungsgeschichte von Haleremita und Gonionemus. Ein Beitrag zur systematischen Beurteilung der Trachymedusen. Z Wiss Zool. 1925;125:374-434.

Kakinuma Y. Life cycle of a hydrozoan, Gonionema oshoro Uchida. Bull Mar Biol Station of Asamushi, Tohoku University. 1971;14:91-7.

Kramp PL. Synopsis of the medusae of the world. J Mar Biol Assoc UK. 1961;40:7-382.

Marchessaux G, Gadreaud J, Martin-Garin B, Thiery A, Ourgaud M, Belloni B, Thibault D. First report of the invasive jellyfish Gonionemus vertens a. Agassiz, 1862 in the Berre lagoon, Southeast France. Biolnvasions Rec. 2017;6(4):339-44.

Matsakis S. Growth of Clytia spp. hydromedusae (Cnidaria, Thecata): effects of temperature and food availability. J Exp Mar Biol Ecol. 1993;171(1):107-18.

Meek MH, Wintzer AP, Shepherd N, May B. Genetic diversity and reproductive mode in two non-native hydromedusae, Maeotias marginata and Moerisia sp., in the upper San Francisco estuary, California. Biol Invasions. 2013;15(1):199-212.

Mikulich LV. The polyps of the poisonous jellyfish Gonionemus vertens vertens L. Agassiz and their behavior. Proc Acad Sci USSR Biol Sci Sec. 1970;190:979-82.

Oldale RN. Cape Cod, Martha's Vineyard \& Nantucket: The Geologic Story. Dennis: On Cape Publications; 2001. p. 224.

Perkins HF. The development of Gonionema murbachii. Proc Acad Natl Sci Phila. 1903;1:750-90.

Pigulevsky SV, Michaleff PV. Poisoning by the medusa Gonionemus vertens in the sea of Japan. Toxicon. 1969;7(2):145-9.

Purcell JE, Båmstedt U, Båmstedt A. Prey, feeding rates, and asexual reproduction rates of the introduced oligohaline hydrozoan Moerisia lyonsi. Mar Biol. 1999; 134(2):317-25.

Reddington E. Data tells an encouraging story for Edgartown Great Pond. 2018; Great Pond Foundation Report. https://greatpondfoundation.org/2018/02/22/ data-tells-encouraging-story-for-egp/.

Reitzel AM, Herrera S, Layden MJ, Martindale MQ, Shank TM. Going where traditional markers have not gone before: utility of and promise for RAD sequencing in marine invertebrate phylogeography and population genomics. Mol Ecol. 2013;22(11):2953-70.

Rodriguez CS, Pujol MG, Mianzan HW, Genzano GN. First record of the invasive stinging medusa Gonionemus vertens in the southern hemisphere (Mar del Plata, Argentina). Lat Am J Aquat Res. 2014;42(3):653-7.

Rugh R. Egg laying habits of Gonionemus murbachii in relation to light. Biol Bull. 1929:57(5):261-6.

Rugh R. Variations in Gonionemus murbachii. Am Nat. 1930;64(690):93-5.

Tambs-Lyche H. Gonionemus vertens L. Agassiz (Limnomedusae) —A zoogeographical puzzle. Sarsia. 1964;15(1):1-8.

Uchida T. A new sporozoan-like reproduction in the hydromedusa, Gonionemus vertens. Proc Jpn Acad. 1976;52(7):387-8.

Yakovlev Y, Vaskovsky VE. The toxic krestovik medusa Gonionemus vertens. Russ J Mar Biol. 1993;19(5-6):287-94.
Ready to submit your research? Choose BMC and benefit from:
- fast, convenient online submission
- thorough peer review by experienced researchers in your field
- rapid publication on acceptance
- support for research data, including large and complex data types
- gold Open Access which fosters wider collaboration and increased citations
- maximum visibility for your research: over $100 \mathrm{M}$ website views per year
At BMC, research is always in progress. 